\title{
What Gets Mapped onto What in the Sex is a Football Game Metaphor in Kenyan HIV/AIDS Campaign Posters?
}

\author{
Magonya Lilian* , Pamela Oloo \\ Department of Linguistics, Maseno University, Kenya
}

Copyright $(\mathcal{C} 2015$ by authors, all rights reserved. Authors agree that this article remains permanently open access under the terms of the Creative Commons Attribution License 4.0 International License.

\begin{abstract}
Susan Sontag, the prolific author of AIDS and its metaphors subscribes to thesis that ailments such as HIV/AIDS, cancer, syphilis and tuberculosis are rich in conceptual metaphors by which they live by. In fact, conceptual and linguistic metaphors coined around the aforementioned ailments serve as cognitive reservoirs upon which embodied experiences with such ailments are conceptually framed. With specific reference to HIV/AIDS, the scientific works of anthropologists, epidemiologists, behaviour change communicators and political analysts affirm that the HIV/AIDS discourse is synonymous to taboo topics associated with sexuality and death. In sub-Saharan Africa, behaviour change communicators have either consciously or unconsciously creatively used pictorial sports metaphors in HIV/AIDS campaign posters. However, few studies in Cognitive Linguistics have investigated the cross-domain mappings of football metaphors in HIV/AIDS campaign posters within the African continent. Specifically on the pervasive usage of the SEX IS A FOOTBALL GAME metaphor. It is against this background that the paper examines the possible cross-domain mappings of the above-referred pictorial metaphor in 9 HIV/AIDS campaign posters used by behaviour change communicators in Kenya between 1988 and 2010.
\end{abstract}

Keywords Football Metaphors, HIV/AIDS, Sexuality, Cross-domain Mappings

\section{Introduction}

Metaphors are cognitive reservoirs creatively utilized by man to register experiences with phenomenon. Said differently, metaphors and human experiences are interlaced, in such a way that the conceptualization of phenomenon is vividly captured by our embodied cognition with metaphors. In this respect, it is common knowledge that HIV/AIDS is a major health concern in sub-Saharan Africa (Sontag, [1], Doka, [2] and Poku, Whiteside and Sandkjaer [3]) According to Kövesces [4] and Lundmark [5] societal challenges within the domains of love, business rivalry, politics, sports and diseases are conceptualized as war, as manifested in expressions such as she fought for her man (own example), Microsoft is ready to fire its first salvo against Apple (Lundmark, [5:p14]), Rival democratic presidential candidates Bill Clinton and Mr Jerry Brown taunted each other for votes (Lundmark, [5:p9]), the two teams are fighting to get a slot in the premier league (own example), We can win the battle against atypical pneumonia (Chiang and Duann, [6]). Given that we are primarily interested in the SEX IS FOOTBALL GAME metaphors used pervasively in Kenyan HIV/AIDS campaign posters, it becomes important to define the place of the football metaphor within the sports semantic domain.

According to George Orwell as cited in Chapanga [7:p64] football and war are interlaced, as captured in the following citation

....soccer like war is a competitive sport where there is a clear winner and loser, strategic thinking, teamwork, preparedness, spectator behaviour, glory of winning and the shame of defeat. The sport is a physical contest making it almost inevitable for allusion to war.

Chapanga [7] further adds that war or the competitive spirit extends beyond the football pitch to the football fans. Said differently, cases of errant fans of a defeated team are known to engage in violent street riots to vent their anger for losing a match. In fact, in Chapanga's perspective, such emotions could have historical ties, for example England and Germany were at one time engaged in war. Therefore, a football match between the one time rivals can be construed as a reenactment of war. For Lundmark, [5:p18], the sports is war metaphor operates under the following domains 


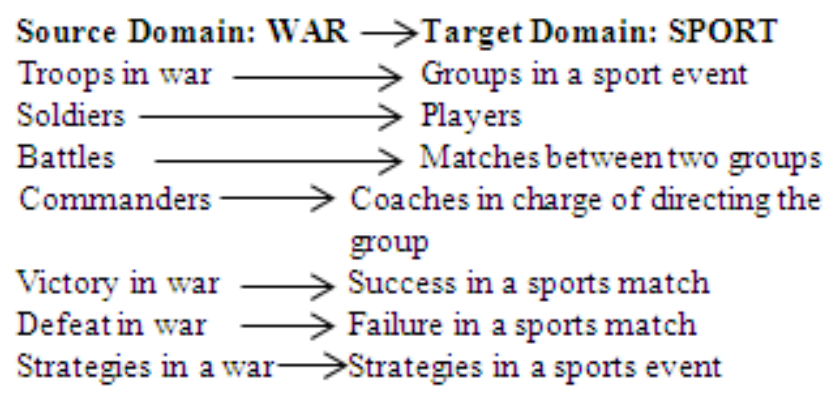

Rivalry is not confined to football but also in war, Lundmark [5] contends that in a war scenario, the role of rival troops engaged in war is to safeguard their territory by using well coordinated strategies spearheaded by their commanders. Put differently, the troops strategize by employing various tactics to defeat their enemies. Likewise, in a sporting event like football, the success of any football team is pegged on teamwork between coaches and their team of players, who employ numerous strategies with the ultimate aim of winning the game. From this standpoint, this unveils the cognitive conceptualization of the SPORTS IS WAR metaphor, captured by the competitive spirit, physical fitness and courage of the players (Kövesces, [4], Lundmark, [5]). Lewadowski [8:p87-88] concurs with both Chapanga [7] and Lundmark [5], in his argument that the football pitch is devoid of terminology such as fair play, as a matter of fact, it is bound by hatred, disregard of all rules, and sadistic pleasure of witnessing violence. In a nutshell, Lewadowski [8] equates football to war minus shooting.

In an attempt to compare war to deadly ailments, Sontag [1], Lundmark [5] and Chiang and Duann [6] argue that the underlying conceptual metaphor for curbing ailments is FIGHTING A DISEASE IS WAR metaphor. Within the field of epidemiology, whenever pathogens invade the human body, immunological defences are automatically launched to combat alien micro-organisms. Simply put, diseases are enemies of man, and their eradication is solely via using medical interventions. In the same vein, just like soldiers who faithfully safeguard their territories against invasions, one has to ensure that diseases are kept at bay as to avoid compromising one's health. In this case, the battleground is the human body where alien micro-organisms and white blood cells engage in war. Besides the white blood cells, there are other soldiers involved in medical war, for instance, health practitioners who explore various strategies to eradicate infectious diseases. However, when the disease records a high mortality rate, then medics would say that humanity has lost the war against a particular pandemic, Lundmark [5:p20-21] summarizes our discussions on illnesses and war under the following cross-domain mappings

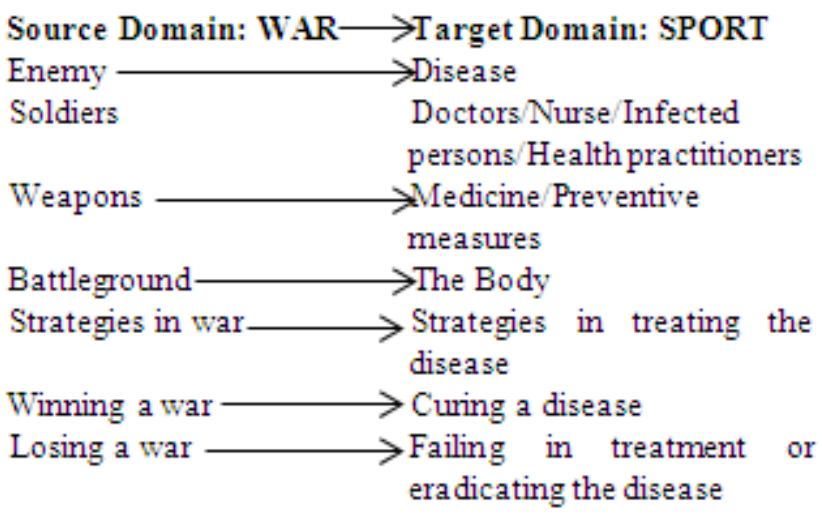

Against such a background, Chapanga [7] and Lewadowski [8] unpack the militarizing language within the football arena. They state that the events and players in a football pitch are normally described using militaristic terminologies. For example, defenders or rearguards mainly fortify positions or thwart their opponents' attempts to score, the strikers launch attacks, both defenders and strikers are conceptualized as foot soldiers, warriors, or even troopers in premier league matches. The coaches are perceived as commanders who provide warriors with winning strategies to neutralize their rivals. As a matter of fact, Lewadowski likens them talented chess players who strategically place their pawns in key positions. Further, senior players serving as commentators are seen as veterans, whereas new acquisitions are perceived as recruits. The referees are compared to army generals who issue matching orders to errant footballers on the pitch. For instance, referees can issue red or yellow cards to the erratic players depending on the nature of the rule breached within the football pitch. The spectators or fans are regarded as player number 11, they heighten the combative spirit in the football arena by either using songs to cheer their respective teams, or by launching "missiles" such as oranges or urine can be thrown or splashed at their opponents (Chapanga, [7:p73]). In the football pitch, key events are centered on the ball, and its speed is referred to as bullet, volley or shot, whereby the interaction between the footballer and the ball is metaphorically compared to the manner in which a soldier uses his gun in firing bullets towards an enemy. Simply put, the football pitch converts into a battlefield, where the offensive team is pitched against the defensive team. This according to Lewadowski [8] transforms the stadium into a conquered fortress. In brief, and borrowing from Charteris-Black as cited in Lewadowski [9], sports like any kind of war is cognitively framed under the SPORT IS A STRUGGLE FOR SURVIVAL metaphor. 
Besides football being predominantly used as a metaphor, it is important to note that football metaphorically lends itself to other sports such as boxing, hunting, racing, cards and sailing. These sports equally demand physical strength, tact, speed and strategy. Examples include SOCCER IS A BOXING BOUT metaphor in expressions like But to their credit, Celtic refused to throw the towel (Arcimavicǐene, [10:p11]; Lewadowski, [9:p96]) or top teams being referred to as heavy weights and less known teams as lightweights, ATTEMPTING TO SCORE IS HUNTING in a sentence such as the wolves have sharpened their teeth in midfield and attack by the addition of Thomas Kahlenberg Lewadowski [9:p96]. Closely related to PLAYING FOOTBALL IS A HUNTING FIELD metaphor is Silaskí ${ }^{1}$ [11:p62] arguments on animal nicknames assigned to clubs. He contends that sports clubs and even players can bear animal nicknames thanks to the PEOPLE ARE ANIMALS conceptual metaphor underlying such nicknames. In other words, the salient attributes of animals or birds can be mapped metonymically onto players. Hence, it is unsurprising to come across a team being referred to as Buffaloes, Bulls or Leopards. A case in point is in Kenya, where one football club is named AFC Leopards, whereas in America there is a basketball team called Chicago Bulls. SOCCER COMPETITION IS A RACE metaphor equally invites speed and strategy, where teams are compared to runners as in the case of Hertha visiting Hamburg as race enters final lap [11:p38], or A SOCCER TEAM IS A SAILING VESSEL metaphor in the expression The way his team capsized in the second half, SOCCER IS A GAME OF CHESS, where tact in soccer is what defines a good play and an experienced coach knows how to checkmate the opposing team. Then another conceptual metaphor that signals tact is SOCCER IS A GAME OF CARDS, where a term such as a joker refers to a player who can change the course of event. Alternatively, there is the SOCCER IS A HUNTING FIELD metaphor, where the hunter is pitched against the prey to denote physical strength and the logic of survival for the fittest. The hunting field metaphor as the variant of SPORT IS SURVIVAL metaphor cognitively frames the football field as a hunting ground. (Lewadowski [9]). Once again, physical force and violence are necessary ingredients of a charged football match (Arcimavičene [10]). In other words, the stadium serves as the hunting ground where strikers double up as hunters who go for the kill and their relentless attempts to score is compared to war. In football hunting field, as explained in Silaskǐ's [11:p63-64] analysis of animal metaphors and metonymy in the Serbian sports discourse, for instance, victory in matches can be conceptualized as VICTORY IS EATING THE OPPONENT metaphor as in the expression The Panthers gobble Buccaneers, or
VICTORY IS FRAGMENTATION OF THE OPPONENT metaphor like Jaguars tear Titans or VICTORY IS TAMING A WILD ANIMAL metaphor as in the expression The Lady tames the stumbling she-wolf. Having outlined the major components of the football discourse, it is important to discuss the Lakoffian conceptualization of the metaphor within the Conceptual Metaphor Theory (CMT).

\section{Theoretical Framework}

The Conceptual Metaphor Theory is the brainchild of George Lakoff, who identifies himself with the experientialist viewpoint of the metaphor as opposed to the Objectivist $^{2}$ school of thought. Experientialists contend that metaphors are neither irrational, nor depict falsity but portray both rational aspects of human cognition. According to Lakoff [12] our conceptual system inclusive of our perceptual and conceptual abilities can be subjected to metaphorical readings. A case in point is the DEATH IS SLEEP metaphor in Dholuo, a Nilotic language in Kenya, where one would say Lilian osenindo (Lilian has slept to denote that Lilian is dead), or it English counterpart Lilian is finally resting in the Lord or LIFE IS A PLAY metaphor, as realized in the expression She is my leading lady, or she always wants to be in the spotlight (Johnson, [13]; Lakoff and Turner, [14:p20]). In CMT, metaphors are engaged in cross-domain mapping where the source domain is mapped onto the target domain. Cases in point are our examples of sleep and plays as source domains, which are mapped onto death and life as target domains respectively. The Lakoffian metaphor classification comprises the following: structural metaphors, orientational metaphors and ontological metaphors. For structural metaphors, a concept is structured as another, for instance the ARGUMENT IS WAR conceptual metaphor is manifested in a linguistic metaphor such as he shot down all her points. Here, arguments are conceptualized as war. Orientational metaphors bank on the spatial orientation in accounting for our experiences with using parameters such as up-down, front-back, deep-shallow, as in the case of HEALTH IS UP and SICKNESS IS DOWN conceptual metaphors in the expressions He is now in top shape after a successful knee surgery and his health is deteriorating. Ontological metaphors are used in expressing our experiences with objects, entities and substances, for example, trouble can be conceptualized as a bounded space where one can either be in and out of trouble. In general, Lakoff [12] holds the argument that metaphors are both ubiquitous and inevitable cognitive frames by which man registers his embodied experience with phenomenon.

\section{Methodology}

1 Silaskǐ [11] gives examples of animal-bird related nicknames of Serbian football clubs such as Eagles, Bulls, Doves, Magpies, Buffaloes and Jaguars among others, where the metonymy of DEFINING PROPERTY OF CATEGORY FOR THE CATEGORY stands in for the salient features of an animal category are transposed onto the football club, via metonymy.
2 Objectivist school of thought argues for rationality, scientific centered logic, literalness as opposed to falsity and creativity of the human language 
Table 1. Number of HIV/AIDS posters drawn from various Non Governmental Organizations

\begin{tabular}{|c|c|}
\hline INSTITUTION & NUMBER OF POSTERS \\
\hline National AIDS Control Council & 1 \\
\hline Family Planning Association of Kenya & 2 \\
\hline Alive and Kicking AIDS campaign & 1 \\
\hline $\begin{array}{c}\text { Confederation of East and Central Africa } \\
\text { Football Association }\end{array}$ & 4 \\
\hline $\begin{array}{c}\text { Liverpool Voluntary, Counselling and } \\
\text { Testing (LVCT) and Care Treatment }\end{array}$ & 1 \\
\hline
\end{tabular}

This paper is an extended research stemming from Dr. Magonya's doctoral thesis which centered on a pragmatic analysis of figurative language used in HIV/AIDS discourse in Kenya. The paper was an in depth analysis of the SEX IS A FOOTBALL GAME metaphor. The study adopted an analytic research design to analyze 9 purposively sampled HIV/AIDS posters used in Kenya between 1998 and 2010. The sampled posters were selected on the basis that they were oriented around the SEX IS A FOOTBALL GAME metaphor. Data collection was primarily library research where we obtained the posters primarily from the Kenyan National AIDS Control Council (NACC) website and the Media/Material Clearinghouse website, the latter is an online archive of HIV/AIDS campaign posters used worldwide. The analyzed posters are listed in Table 1.

Finally, data was analyzed qualitatively under the guidance of CMT, to compute the possible cross domain mappings of the SEX IS A FOOTBALL GAME metaphors in Kenyan HIV/AIDS posters.

\section{Discussion}

Poster 1 reads CHAMPIONS PLAYS SAFE!, it portrays the Kenyan football team together with their former football coach called Jacob "Ghost" Mulee (right hand side) and a former Minister of Sports, Honorable Najib Balala (left hand side). According to Chapanga [7] and Lewadowski [8], a football coach like Jacob Mulee is construed as a commander, whose role is to ensure that players employ the best strategies to neutralize the offensive team. For the effective application of the winning strategies, teamwork involving the coaches, players and the support of relevant government agencies such as the Ministry of Sport, (which is metonymically presented by Honorable Najib Balala), impact on the general performance of a team (Lundmark, [5]). As previously stated by Silaskî [11], the football metaphor lends itself to other semantic domains like in Behaviour Change Communication, where aspects related to sexuality and relationships are construed as a game. Hence, an expression such as playing sex denotes sexual intercourse, while in the Black American culture, the term a player refers to a sexually promiscuous man. Further, in the context of relationships, whenever one person downplays advances of another, it is referred to as playing hard to get. Fernández [19] argues that the term play the field refers to being sexually active, whereas to score means to copulate. Further, to play away means to commit adultery. In the HIV/AIDS era, the playing field associated with being sexually active, hence the need to either use protection in curbing HIV/AIDS or being faithful to one partner. Moreover, the communicator employs a pictorial metaphor of the Kenyan football team to evoke both structural metaphors such as UNITY IS STRENGTH, FIGHTING HIV/AIDS IS WAR and USING PROTECTION AS A WINNING STRATEGY IS PLAYING SAFE metaphors. In brief, fighting HIV/AIDS just like football, requires teamwork from various partners, such as Health Ministries and Non Governmental Agencies engaged in the fight against the HIV/AIDS pandemic. In this case, the possible cross- domain mappings are outlined

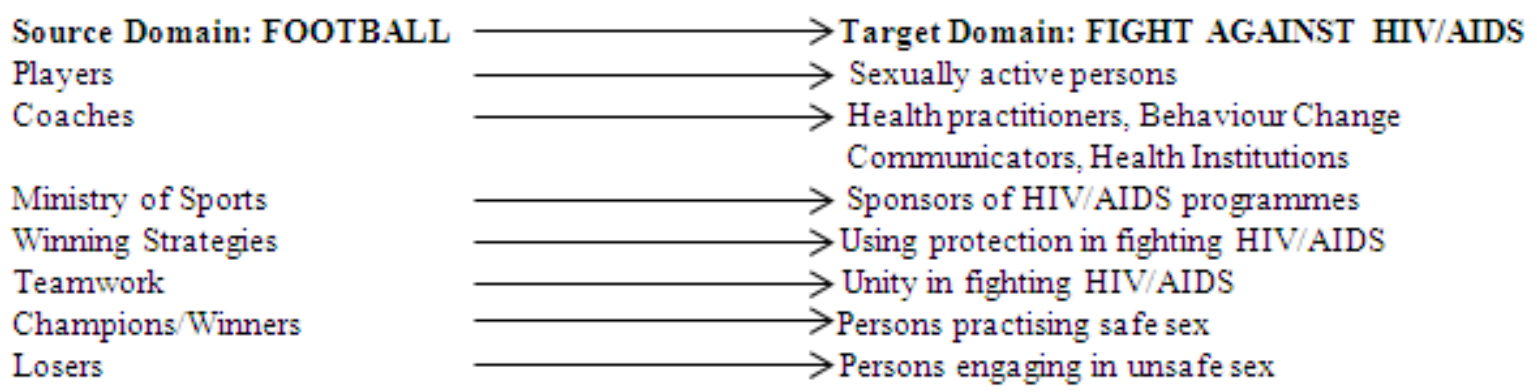




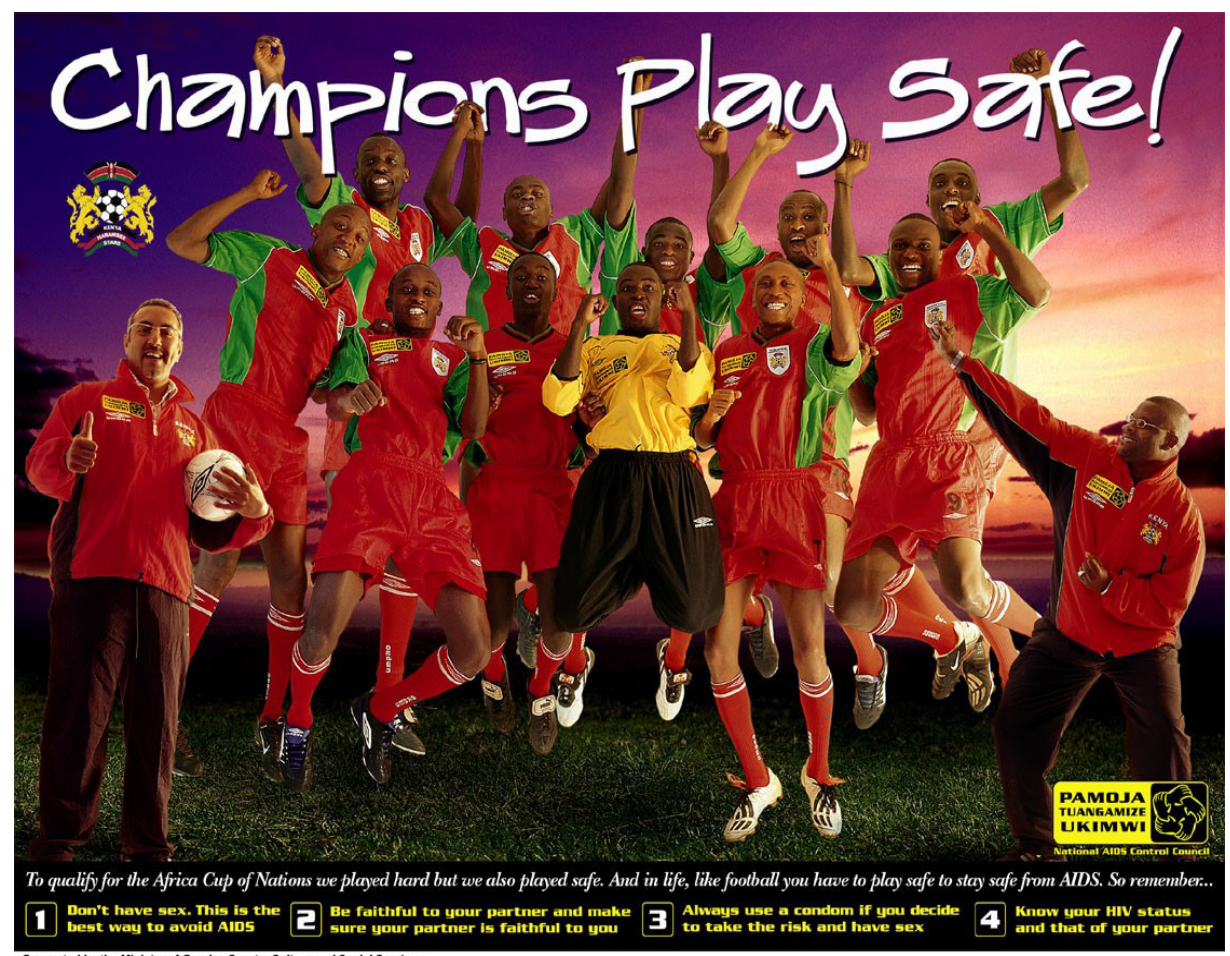

Source: NACC [15]

Website:http://www.nacc.or.ke/2007/index.php

Poster 1: (2003) Pamoja Tuangamize Ukimwi (Together we can defeat AIDS campaign)

Poster 2 reads To win a good match defending is a must. For family planning and protection against STIs and AIDS. Use a condom. The poster uses the image of a striker near the goalpost who fails to score because his shot has been blocked by the wall formed by opponents. The latter comprise six players dressed up in condoms from head to toe, with each player representing a letter that forms the term condom. The pictorial metaphor shows that the players are advocating for safe sex under PRACTISING SAFE SEX AS A DEFENCE STRATEGY IS WEARING A CONDOM conceptual metaphor. Put differently, the formation of wall in front of a goalpost is metaphorically construed as the way the condom shields one from contracting HIV/AIDS. As stated by Chapanga [7] and Lewadowski [8], strikers are construed as either foot soldiers or warriors who launch attacks on the rival team. In Poster 2, the strikers are mapped onto sexually active persons, whereas the act of shooting is mapped onto copulation. Beside the goalpost is a referee who acts as an arbitrator by ensuring that the rules of football are strictly followed. The referee metaphorically represents the role of health practitioners in fighting HIV/AIDS (Lewadowski, [9]). From the foregoing, winning a match is the core business of any team as stated by Chapanga [7]. Thus, to effectively combat the AIDS pandemic and for family planning purposes, using protection is an imperative defence strategy. The posters cross-domain mappings are outlined as follows

Source Domain: FOOTBALL
Players/Strikers
Fining a shot (score)
Missing to score
Referee/Commanders
Defence by forming a wall
Football match
Winning a match

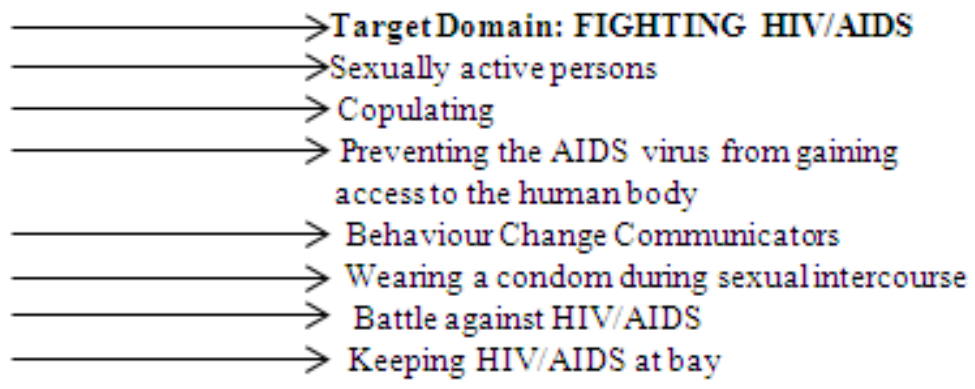




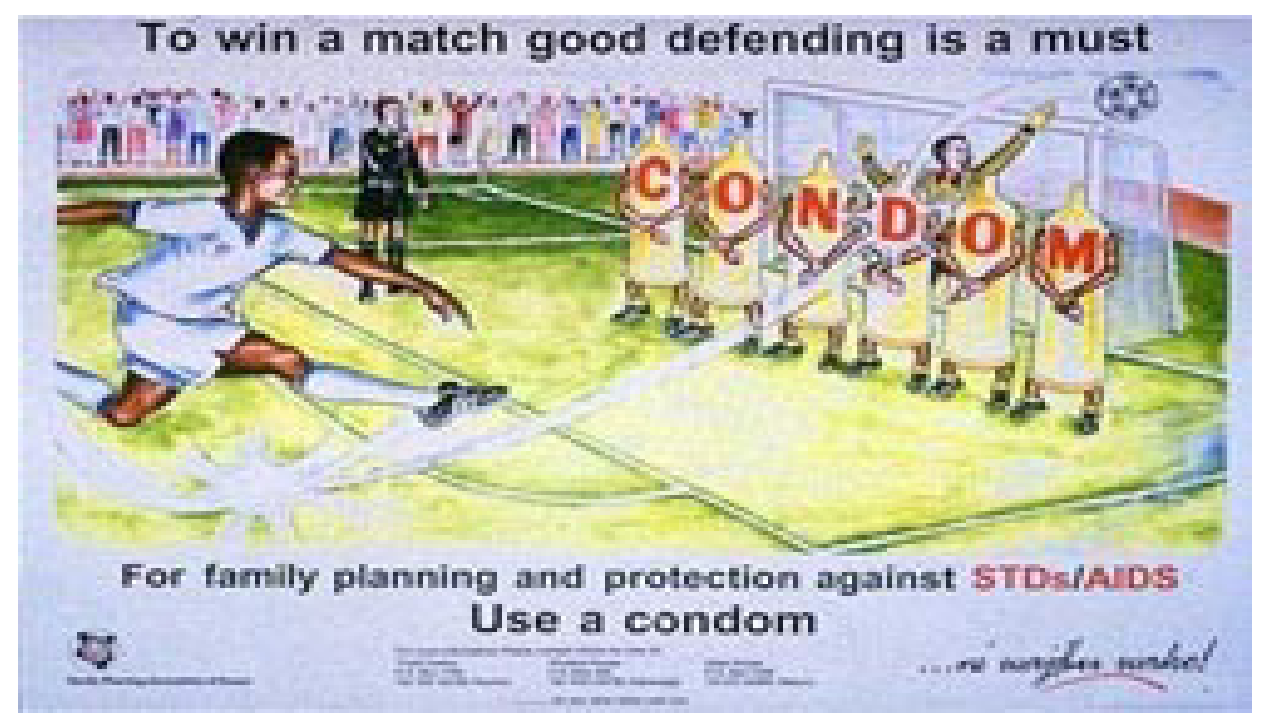

Source: Media/Materials Clearing House [16]

Poster 2. (1998) Family Planning Association of Kenya

Poster 3 reads Smart Players always wear "socks". Join the AIDS team. Use a condom. The poster suggests that in the HIV/AIDS era, smart players always wear "socks". Literally speaking, socks are worn by players as a protective measure against injuries. In this pictorial metaphor, socks metaphorically represent condoms as captured by WEARING "SOCKS" AS A PROTECTIVE STRATEGY BY SMART PLAYERS IS WEARING A CONDOM structural metaphor. Put differently, people who practise safe sex are like smart players. This suggests that they are cautious about their sexual liaisons. Unlike those who do not practise safe sex. Therefore, membership into the AIDS team is signaled by condom usage which still evokes the UNITY IS STRENGTH structural metaphor as seen in Poster 1. The cross domain mappings are as follows

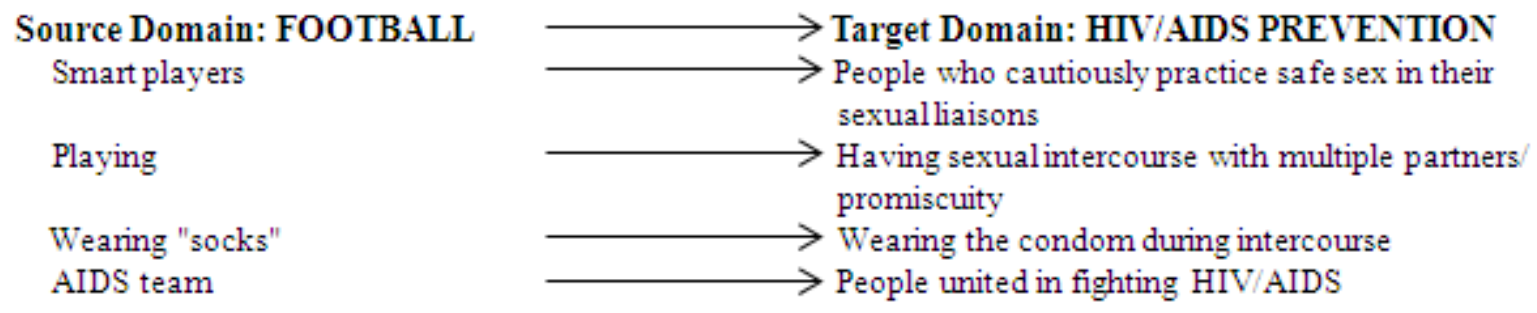

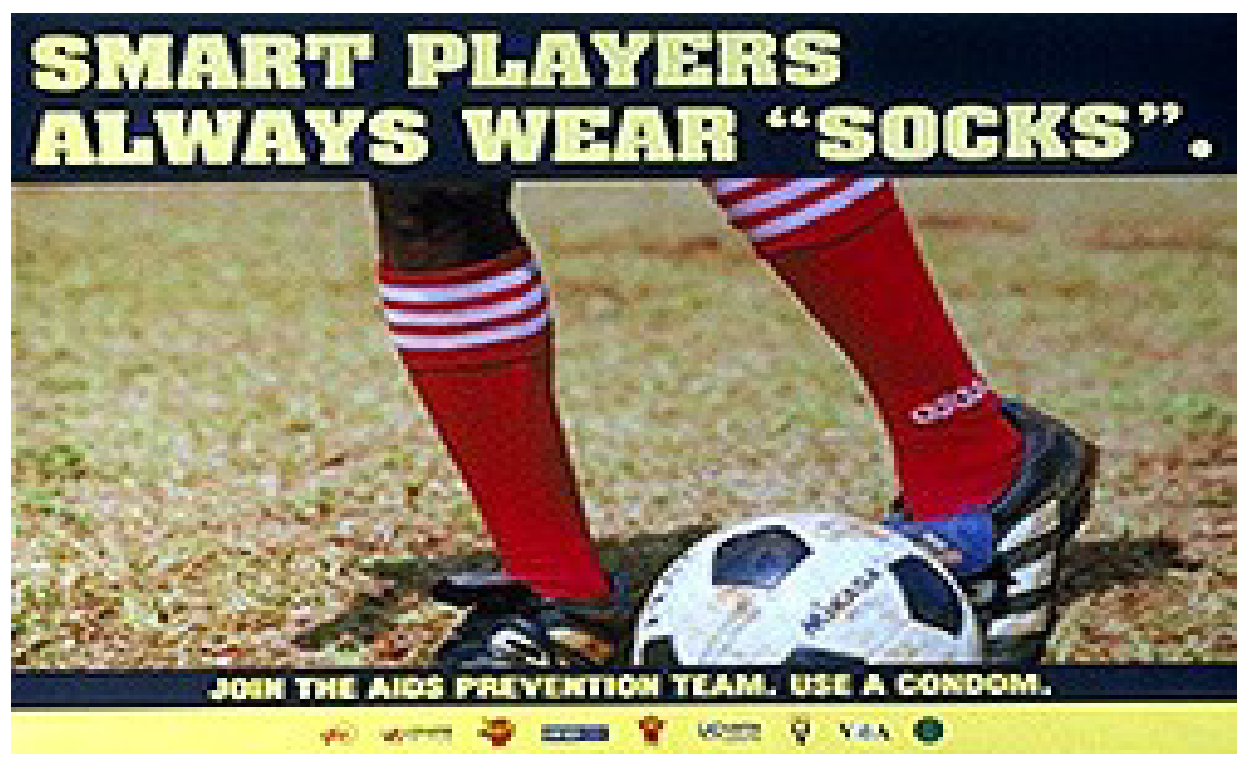

Source: Media/Material Clearing House [16]

Poster 3. (2000) Confederation of East and Central Africa Football Association (CECAFA) poster 
Poster 4 like Poster 3 resorts to another strategy in fighting HIV/AIDS, where tact is imperative as stated by Kövesces [4]. The poster has message Use your head. Join the AIDS prevention team. Think before you play around. According to Chapanga [7], footballers either strategically resort to using their legs or heads to score a goal. In the context of Poster 4, the head metonymically represents the brain which is the locus of strategic thinking, especially for games such as chess (Silaskǐ [11]). Moreso, Esau [20:p28] argues that the human mind is the cognitive throne of abstract thinking, memory pattern recognition, inductive and deductive reasoning, visual imagery, creativity, problem solving and decision making. He adds that logical thinking is imperative in curbing HIV/AIDS. Therefore, an important aspect in fighting HIV/AIDS demands rational human beings who first consider the repercussions of engaging in unsafe sex. The conceptual metaphors in the poster are REASONING IS USING ONES HEAD, PROMISCUITY IS PLAYING AROUND and UNITY IS STRENGTH. The cross domain mappings for Poster 4 are outlined as follows:
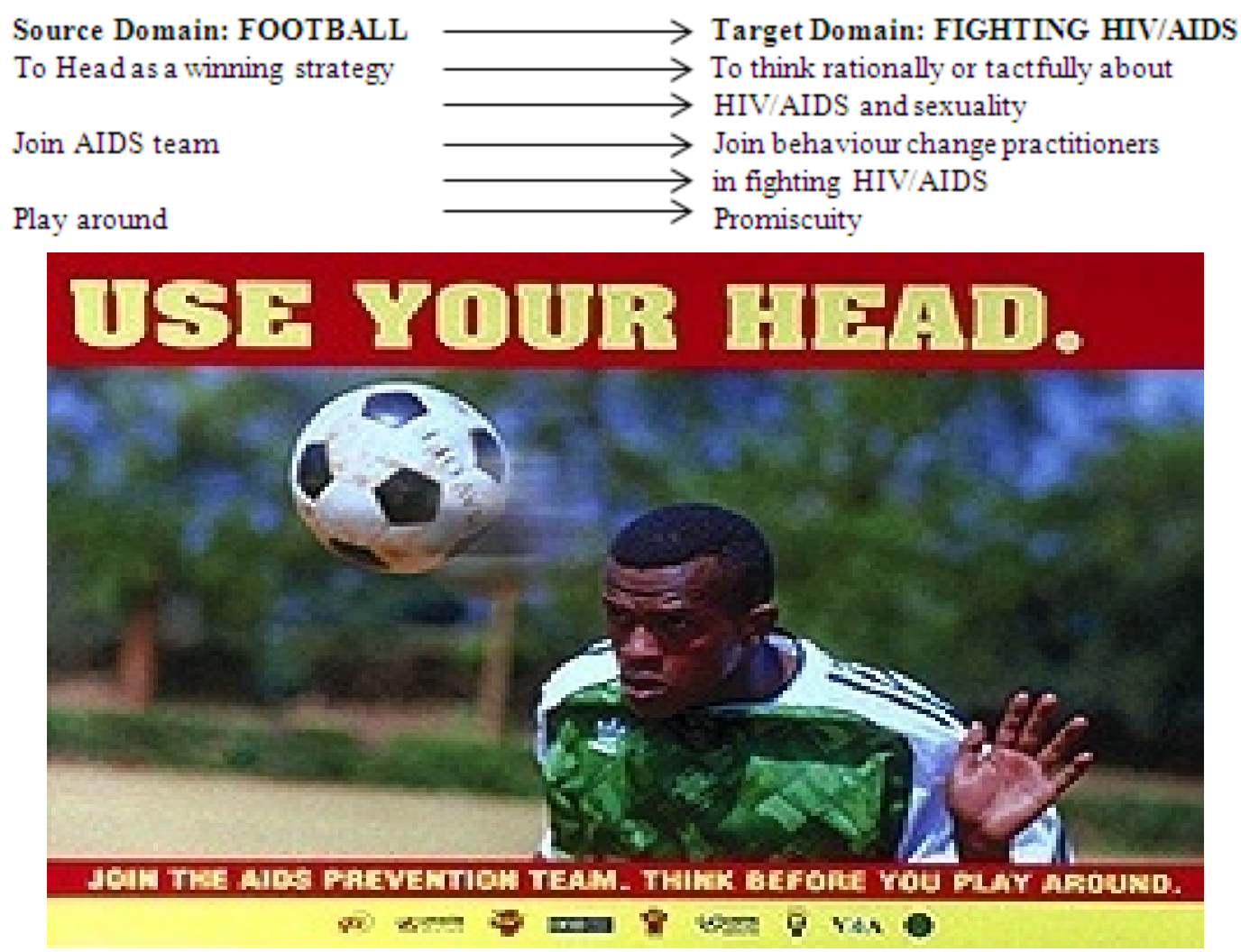

Source: Media /Materials Clearing House [16]

Poster 4. (2000) Confederation of East and Central Africa Football Association

Poster 5 bears the message Kick AIDS out of AFRICA. Talk to your teammates \& Fans about AIDS prevention. BREAK THE SILENCE. There are several metaphors operating in the poster, there is an ontological metaphor for instance THE AFRICAN CONTINENT IS A CONTAINER, whereby Africa is construed as a bounded space. In the said container, things can either be contained within it or remain outside the continent. Naturally, the continent embraces positive values and rejects counterproductive issues. From the foregoing and in line with the AIDS pandemic, the communicators are advocating for its eradication using ERADICATING HIV/AIDS IS KICKING AIDS OUT OF AFRICA conceptual metaphor. As seen in Posters 2, 3 and 4 where strategies such as building a wall at the goalpost, wearing "socks" or heading are necessary for winning a match. Similarly, kicking a ball away from the defence team's goal post is a strategy of barring the rival term from scoring. Further, given that players are supposed to sensitize both fans and other players on HIV/AIDS, SENSITIZING PEOPLE ON HIV/AIDS IS TALKING ABOUT AIDS structural metaphor works alongside the linguistic metaphor break the silence, whose ontological metaphor is SILENCE ON HIV/AIDS IS A BRITTLE SUBJECT. Put differently, by talking about HIV/AIDS, they will break the silence around the muted HIV/AIDS discourse. The cross domain mappings are as follows

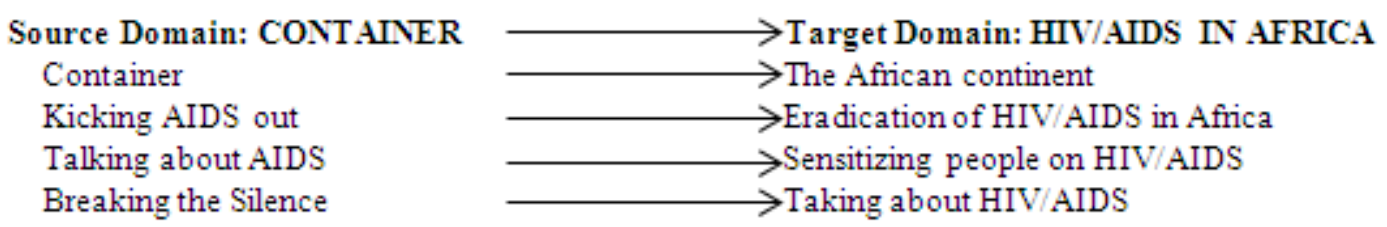




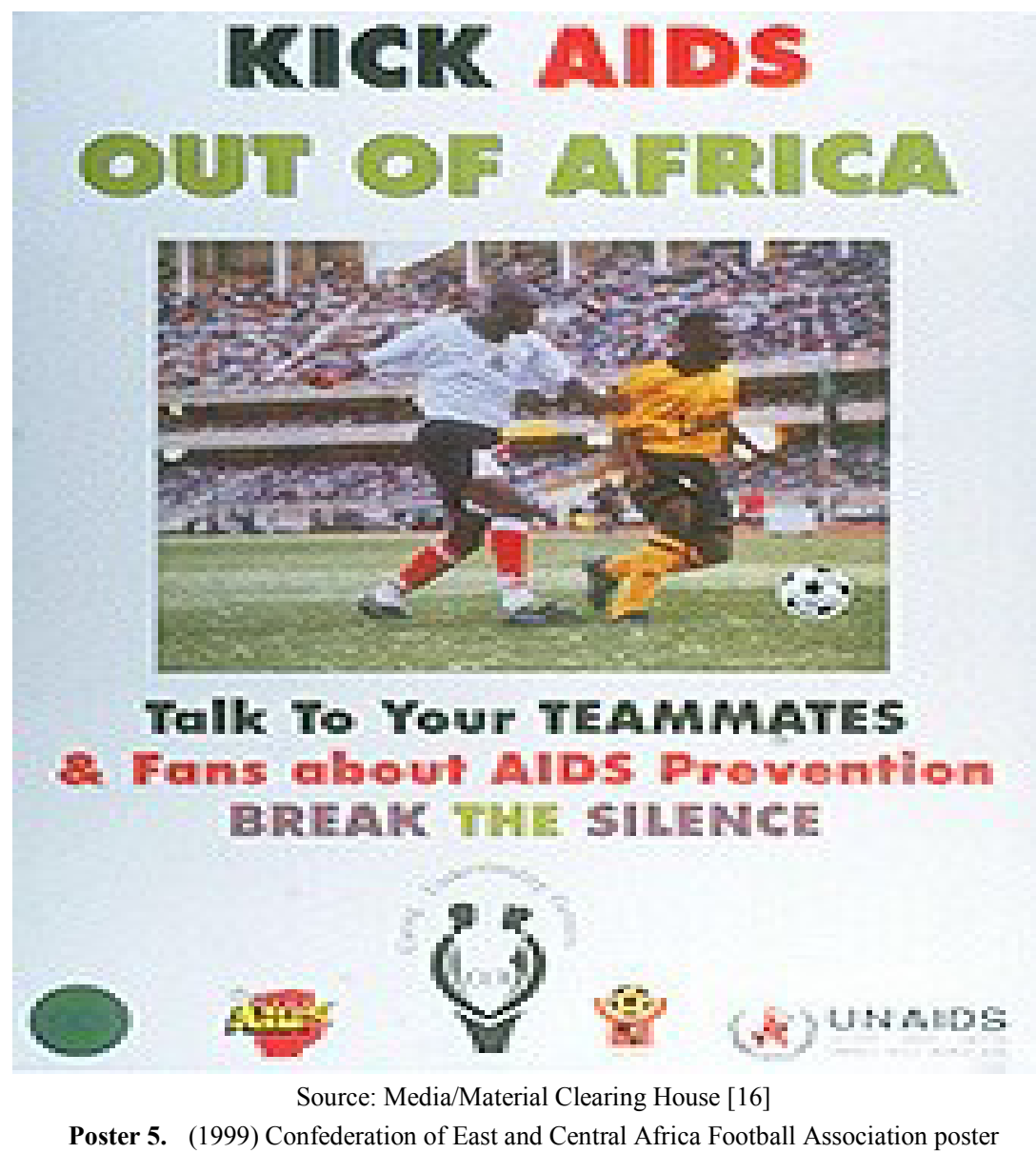

Poster 6 bears the message PLAYING AT HOME BEATS PLAYING AWAY. JOIN THE AIDS PREVENTION TEAM. BE FAITHFUL TO YOUR PARTNER. As earlier stated in Poster 1, sexuality is construed as a game and there are added advantages for players, especially when the match is played within the home ground or a familiar territory, as opposed to unfamiliar grounds. Therefore, playing at home literally denotes having sex with one faithful partner. Whereas, playing away which means committing adultery (Fernandez [19]). In the poster, the two sides are pitched against each other, where the merits of playing at home outweigh those of playing away. The analogy here is likened to a boxing contest were playing at home trounces playing away (cf. Lewadowski [9]; Arcimavičene [10]). Here, the communicators are confirming that winners are those having stable sexual partners, as opposed to promiscuous persons. The structural metaphor in Poster 6 is FIDELITY IN RELATIONSHIPS IS MAINTAINING STABLE RELATIONSHIPS metaphor, which hosts conceptual metaphors like PROMISCUITY IS PLAYING AWAY and FIDELITY IS PLAYING AT HOME. The cross domain mappings are as follows

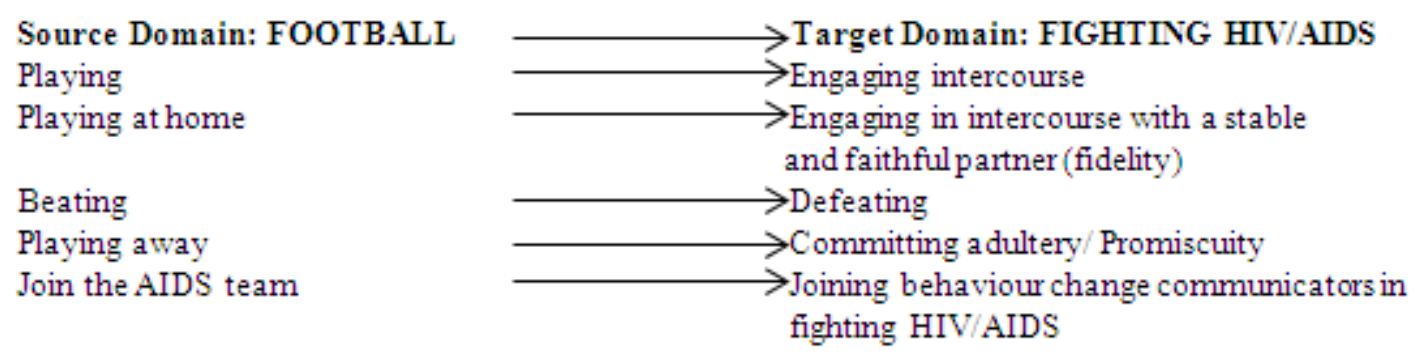




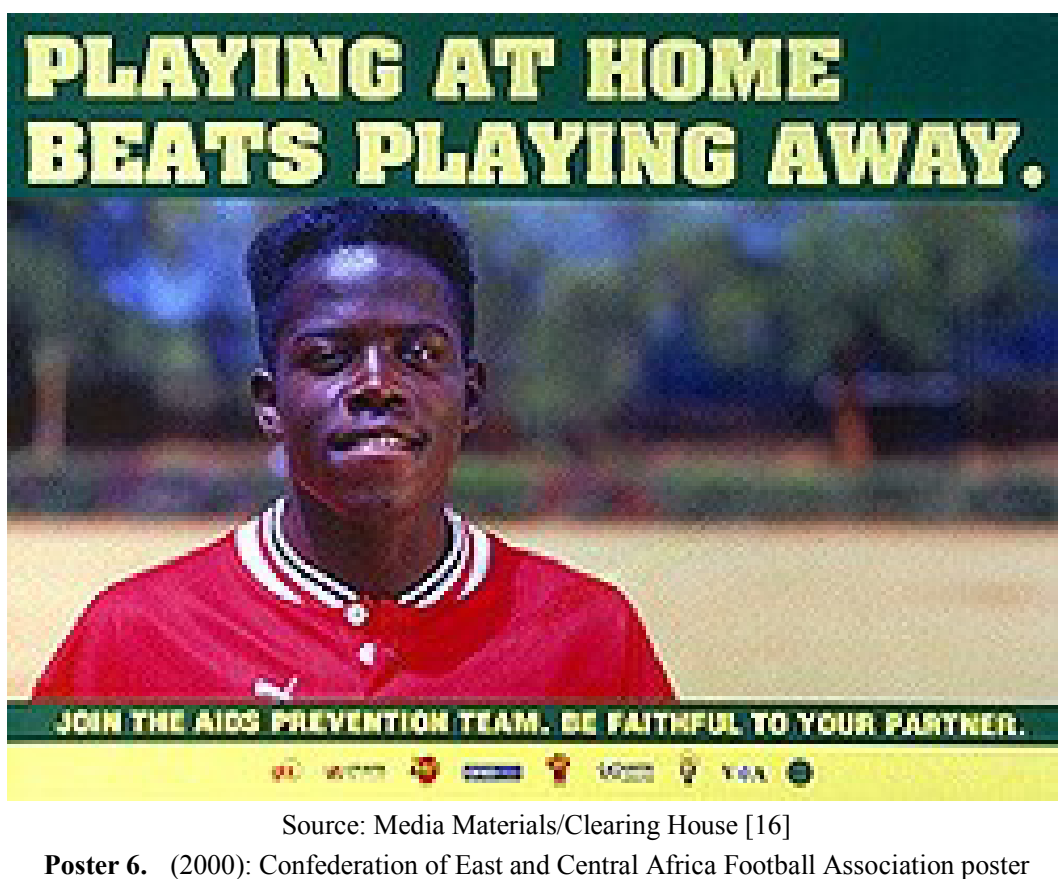

Poster 7 reads Avoid getting a red card. Think before you act. Prevent yourself from STDs and HIV/AIDS. Use a condom. The terms red card, STDs and HIV are written in red. In Cognitive Linguistics, colors are regarded as a subcategory of metaphors because of their connotative meanings (Rasekh and Ghafel,[21]). According to Qiang [22] and He [23], the red color serves as a warning sign, which to some extent demands some restraint. It is not by coincidence that the communicators are writing the term red card in red. This serves as double highlighting to signal the consequences of defying preventive measures against HIV/AIDS, under DEFYING HIV/AIDS PREVENTION INTERVENTIONS IS TANTAMOUNT TO GETTING A RED CARD conceptual metaphor. As stated by Lewadowski [9], referees are the equivalent of army generals who not only issue orders, but also give red or yellows to erratic players in the football pitch. In the context of HIV/AIDS, failure to use protection is synonymous to defying the required preventive measures against HIV/AIDS. Therefore, persons engaging in risky sexual behaviour deserve red cards for defying AIDS prevention initiatives. Further, the audience is being advised to think before they act, to protect themselves from STDs and HIV/AIDS. The following mappings featured in Poster 7.

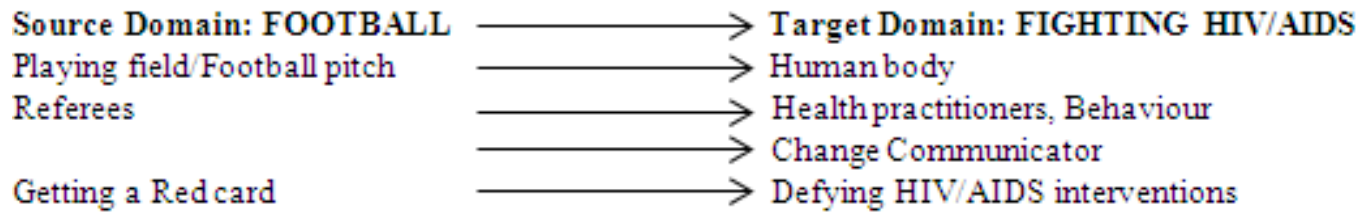




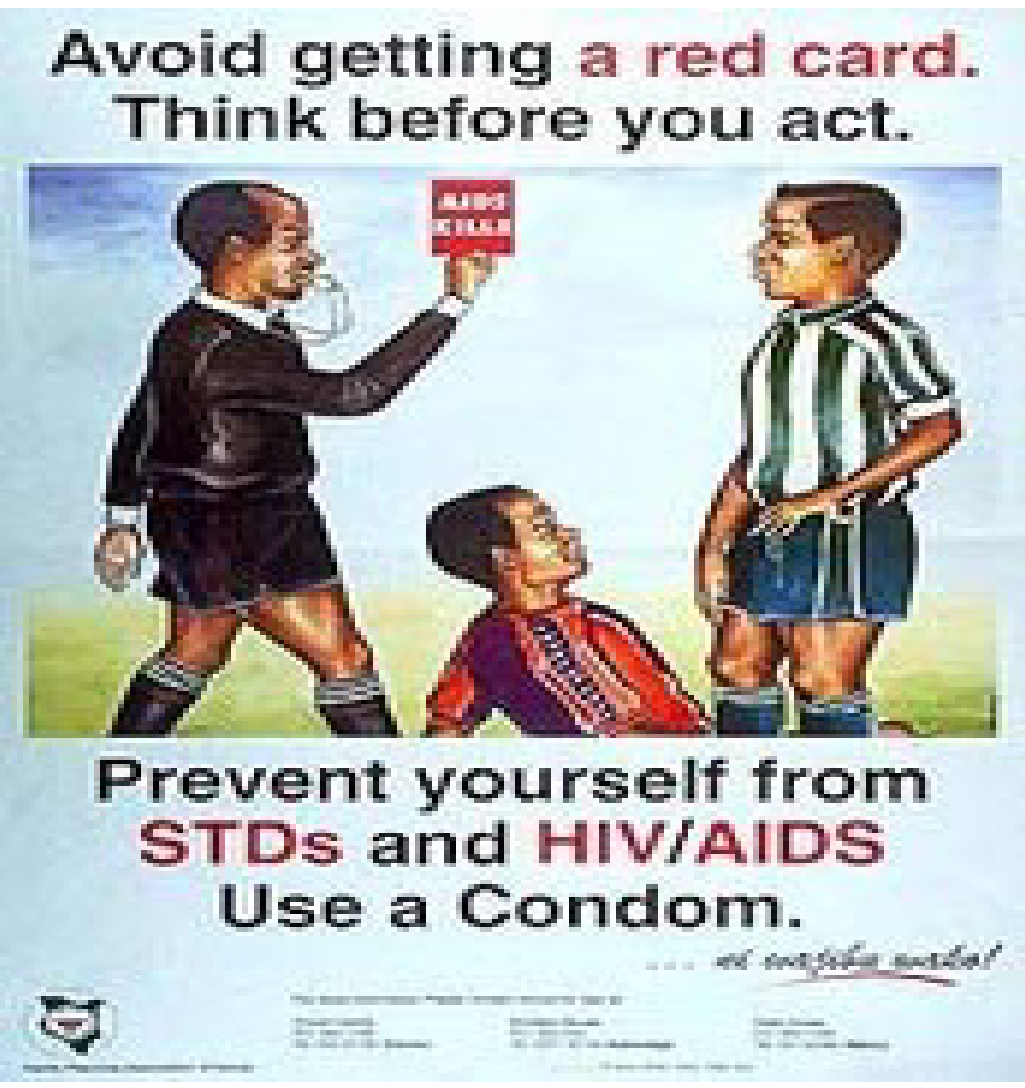

Source: Media/Material Clearing House [16]

Poster 7. (1998) Family Planning Association of Kenya

Closely related to Poster 7 is Poster 8 carrying the message written against a red background in white, HIV AIDS can be avoided by remaining faithful to your partner provided neither of you were HIV positive when you first met. Unfair play in a relationship could cost you a lot more than a red card. The message advocates for faithfulness among sexually active persons. Like in Poster 7, the image of a referee recurs in Poster 8, where as previously stated, the referee is the equivalent of an army general who issues red cards to defiant players. However, in Poster 8 promiscuous persons engaging in unfair play are seemingly frustrating efforts used in mitigating the spread of the scourge. Furthermore, unfair play is seen as a priced commodity whose repercussions are incomparable to a footballer served with a red card, as captured in the linguistic expression unfair play can cost you more than a red card. The conceptual metaphors here are DEFYING THE RULES OF HIV PREVENTION INTERVENTIONS IS ASSIGNED A COSTLY PRICE or DEFYING THE RULES OF HIV PREVENTION IS UNFAIR PLAY IN RELATIONSHIPS.

Source domain: FOOTBALL Unfair play

Costs

Red card
Target domain: FIGHTING HIV/AIDS

Reckless sexual behaviour

Grave repercussions for contracting HIV/AIDS

Disqualification from the AIDS prevention team. 


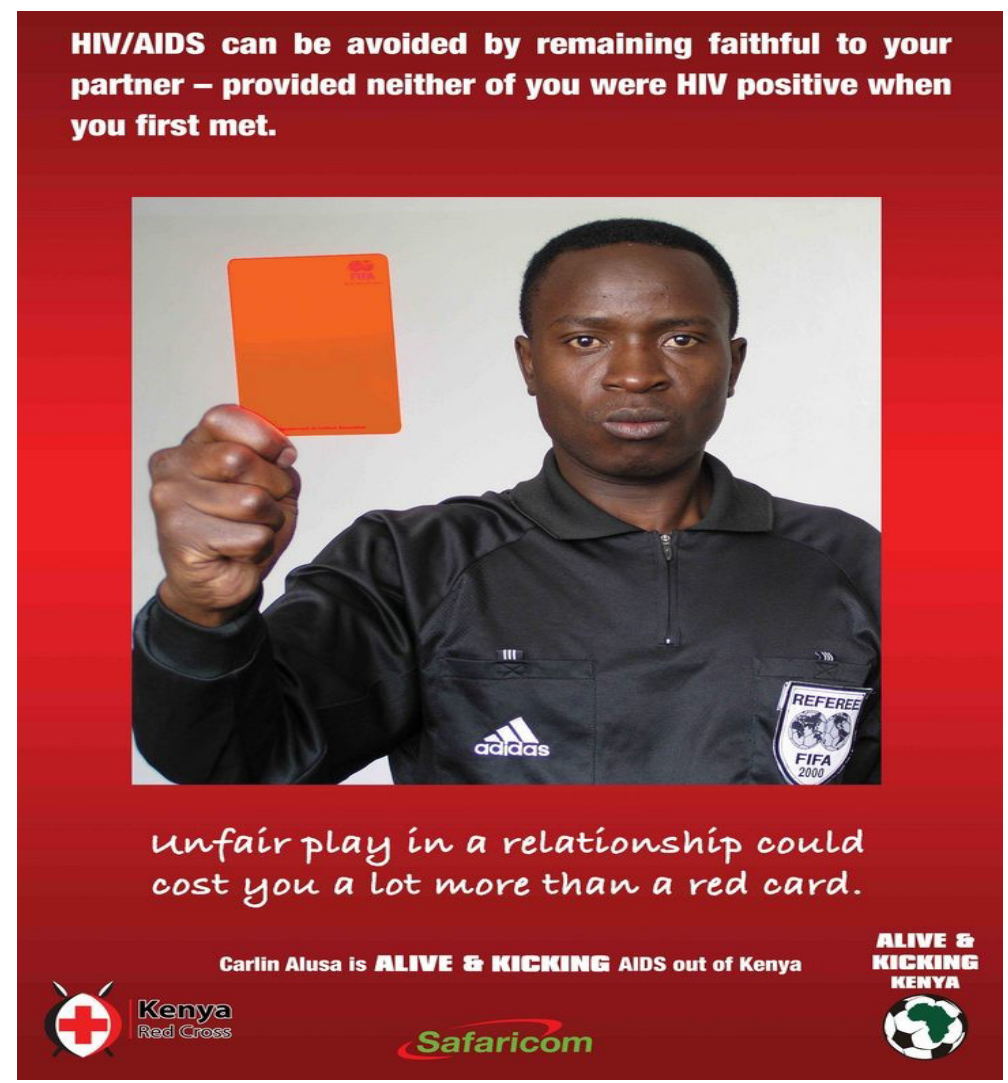

Source: Alive and Kicking AIDS [17] campaign

Poster 8. (2005) Alive and Kicking AIDS campaign poster

Poster 9, employs English, Kiswahil and Sheng'3, the message reads Jitambue Leo! Ingia kwa network. Be a real man Know your status. Be the referee of your life. Control game poa! (Know your status, Join the network. Be a real man. Know your status. Be the referee of your life. Be the referee of your life. Control a good game). The message stresses on the need for people to know their HIV status under KNOWING ONES STATUS IS ENTERING THE HIV/AIDS NETWORK metaphor and TAKING CHARGE OF ONES SEXUALITY IS BEING A REFEREE OF ONES LIFE metaphor, where one takes full charge of his or her sexuality in the same way a referee takes charge of the football match. Alongside the cited metaphors, the poster equally accommodates ENGAGING IN SAFE SEX IS CONTROLLING A GOOD GAME metaphor. Said differently, the communicator is advocating for people to take control of their sexuality. The cross domain mappings here are as follows
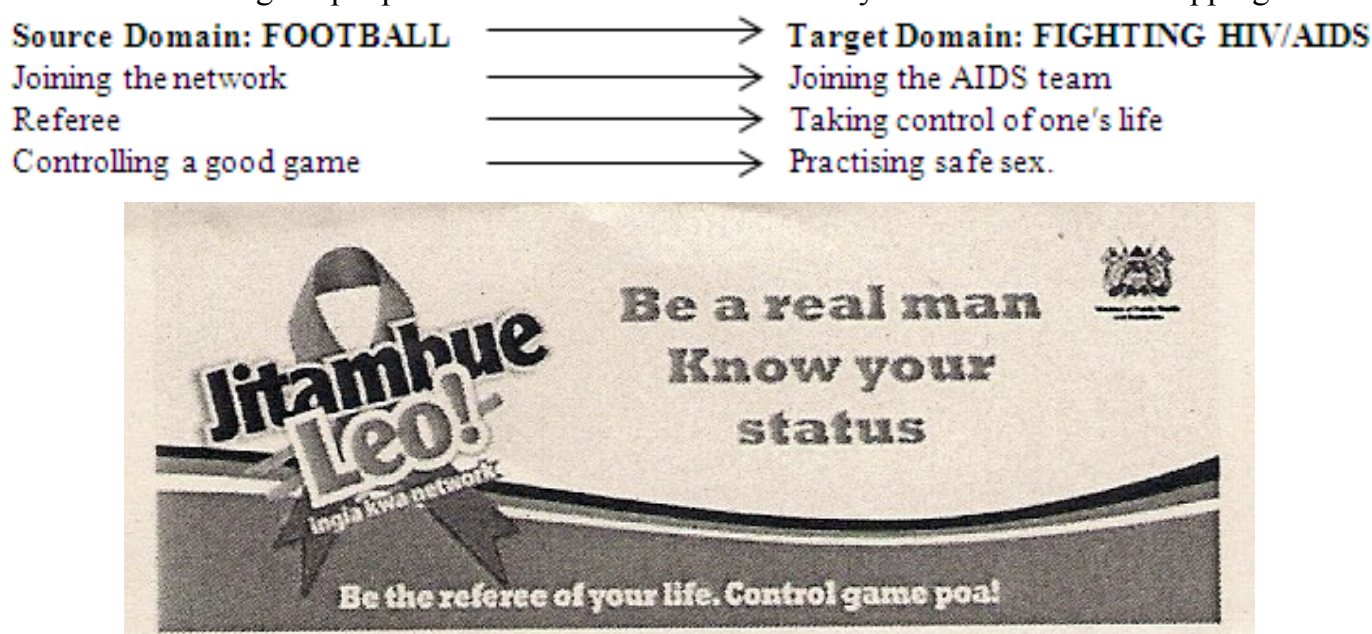

Source: LVCT and Care Treatment [18]

Poster 9. JITAMBUE LEO ! INGIA KWA NETWORK

3 According to Kang'ethe [24]) English and Kiswahili are official languages, while Sheng' is a mixed language that borrows for English, Kiswahili and other Indigenous languages spoken in Kenya 
It is noteworthy to mention that besides the pervasive usage of the SEX IS A FOOTBALL GAME metaphor in Kenya, and going by Lewadowski [9] and Arcimaviciene [10], assertions that other sports such as boxing and sailing coexist with football metaphors in various domains. Likewise, other sports such as cards and fencing as seen in Posters 10 and 11 , which have been employed in AIDS campaigns in Switzerland and America respectively. The sports metaphors in Posters 10 and 11 are analyzed below:

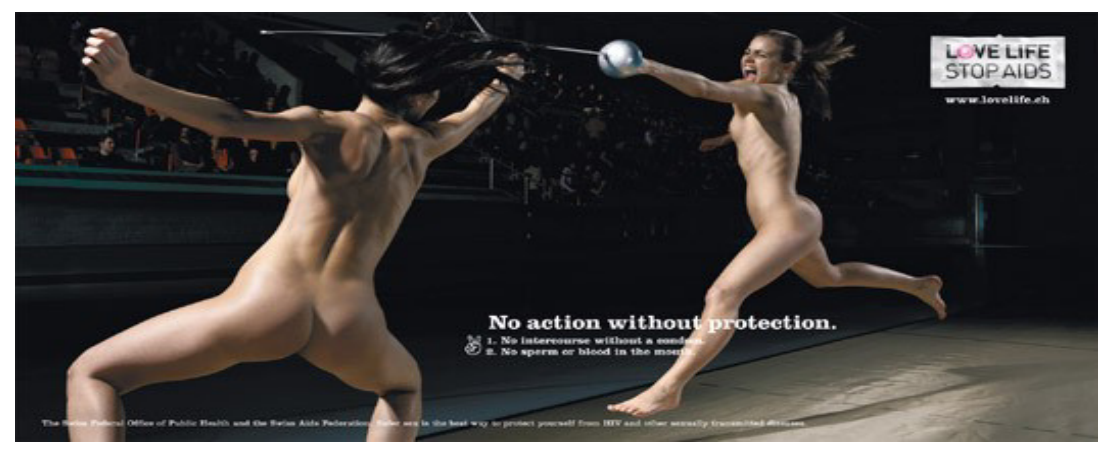

Source: Swiss Federal Office of Public Health [25]

Poster 10. SFOPH SWISS LOVE LIFE STOP AIDS CAMPAIGN

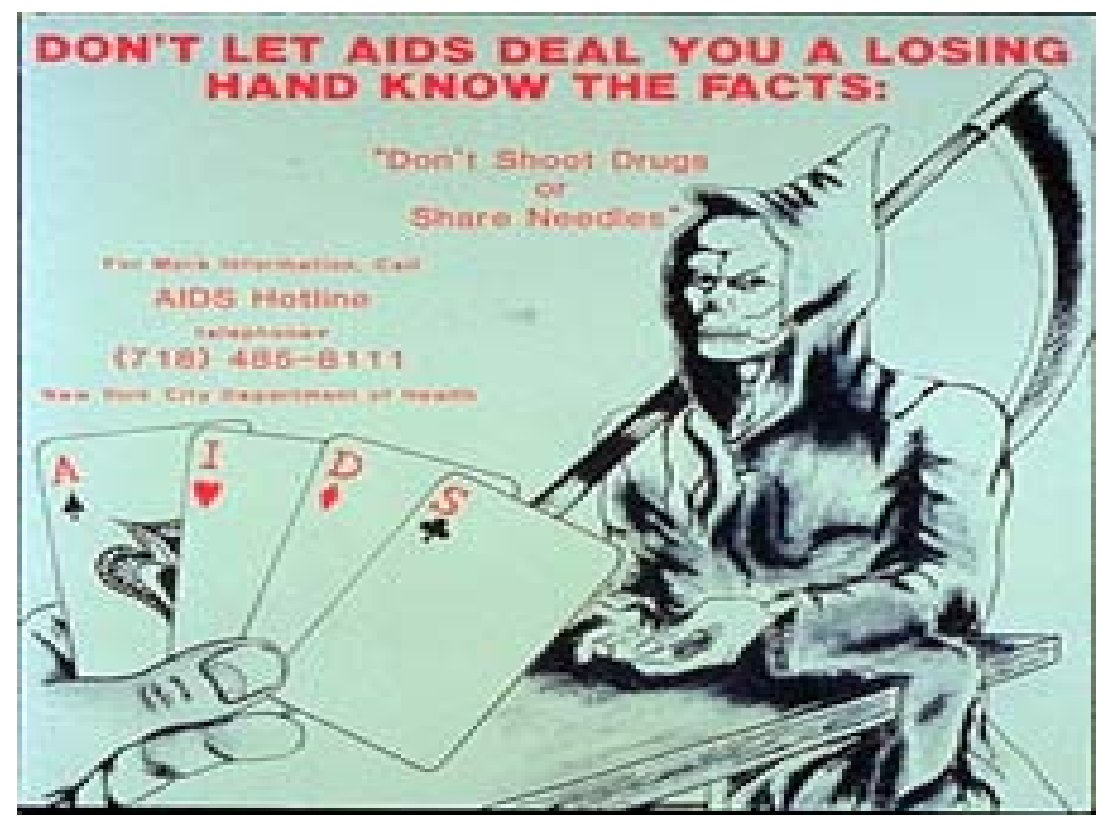

Source: Media/Materials Clearing House [16]

Poster 11. New York City Department of Health AIDS campaign poster targetting Drug Users

On one hand, Poster 10 as stated in Magonya \& Oloo [26] employs images of nude women engaging in fencing as a risky sport without any protective gear. The poster's message is No action without protection. The conceptual metaphor operating here is UNSAFE SEX IS RISKY SPORTS WITHOUT PROTECTIVE GEAR. On the other hand, Poster 11 shows a hand holding cards that spell AIDS that have been dealt out by Grim reaper aimed with his scythe. In Cognitive Linguistics, Grim reaper personifies death or HIV. (Lakoff and Turner, [14], Magonya, [27], Magonya \& Oloo, [26]) The poster contains the message that is double-highlighted since it is written both in red and in capital letters DON'T LET AIDS DEAL YOU A LOSING HAND KNOW THE FACTS. Don't shoot drugs or Share needles. The poster warns drug users against giving AIDS an upper hand either by shooting drugs or sharing needles. The term deal is associated with card games where the action of dishing out cards is referred to as dealing. In Poster 11, needle sharing or shooting drugs exposes one to the risk of infections and is metaphorically synonymous to letting Grim reaper or HIV/AIDS deal out cards. The conceptual metaphors in the poster are HIV /AIDS IS GRIM REAPER, DEALING A LOSING HAND IN THE FIGHT AGAINST HIV/AIDS IS SHOOTING DRUGS OR SHARING NEEDLES and SHOOTING DRUGS IS INJECTING ONESELF WITH A NEEDLE conceptual metaphors.

\section{Conclusions}

From the above discussions, evidently, the SEX IS A 
FOOTBALL GAME metaphor exists in Kenyan HIV/AIDS posters. It is a truism that behaviour change communicators extensively capitalize on the FIGHTING HIV/AIDS IS A STRUGGLE FOR SURVIVAL and FIGHTING AIDS IS WAR metaphors as the foundation pillars of their messages. Further, it cannot be overemphasized that HIV/AIDS shares aspects of war that equally characterizes any competition. The presence of pictorial football metaphors and linguistic metaphors in HIV/AIDS campaign posters such as calls for teamwork under UNITY IS STRENGTH and USING PROTECTION IS PLAYING SAFE conceptual metaphors (Poster 1), PRACTISING SAFE SEX AS A DEFENCE STRATEGY IS WEARING A CONDOM (Poster 2), WEARING "SOCKS" AS A PROTECTIVE MEASURE BY SMART PLAYERS IS WEARING A CONDOM (Poster 3),

REASONING IS USING ONES HEAD (Poster 4), ERADICATING HIV/AIDS IS KICKING AIDS OUT OF AFRICA (Poster 5), PROMISCUITY IS PLAYING AWAY and FIDELITY IS PLAYING AT HOME (Poster 6), DEFYING HIV/AIDS PREVENTION INTERVENTIONS IS TANTAMOUNT TO GETTING A RED CARD (Poster 7), DEFYING HIV PREVENTION INTERVENTIONS IS UNFAIR PLAY IN RELATIONSHIPS (Poster 8), TAKING CHARGE OF ONES SEXUALITY IS BEING A REFEREE OF ONES LIFE and ENGAGING IN SAFE SEX IS CONTROLLING A GOOD GAME (Poster 9). In conclusion, the HIV/AIDS campaign posters are rich in metaphors by which it lives by. Moreover, the SEX IS A FOOTBALL GAME metaphor is just but one sport by which man's embodied experience with fight against HIV/AIDS is cognitively registered.

\section{REFERENCES}

[1] Sontag, S. (1988). AIDS and its metaphors. London : Penguin Group.

[2] Doka K, (1997). AIDS, Fear and Society. Challenging the Dreaded Disease. Washington, DC: Taylor and Francis Publishers.

[3] Poku, N., Whiteside, A. and Sandkjaer, B. (2007). AIDS and Governance. Hampshire:Ashgate Publishing Limited.

[4] Kövesces, Z. (2002). Metaphor. A Practical Introduction. Oxford: Oxford University Press.

[5] Lundmark, C. (2010). A Cognitive Study of War Metaphors in Five Main Areas of Everyday English: Politics, Business, Sports, Disease and Love. Website: http://www.diva-portal.org/smash/get/diva2:397473/FULLT EXT01.pdf. Retrieved on 10.10.2014

[6] Chiang, W. and Duann, R. (2007). Conceptual Metaphors for SARS: 'War' between Whom? In Discourse and Society. Volume 18 (5), pp. 579-602. Los Angeles, London: Sage Publications

[7] Chapanga, E. (2004). An analysis of the war metaphors used in Spoken Commentaries of the 2004 Edition of the Premier Soccer League Matches in Zimbabwe. In Zambezia, XXX1 (i), (ii)

[8] Lewadowski, M. (2009). Metaphors from other sports in the Language of Soccer evidence from English and Polish. Language, Communication, Information. In Nowark, P. and Nowakowski, P. (Eds). 4/2009, pp. 29-48

[9] Lewadowski, M. (2010). The Rhetoric of Violence in Polish and English Soccer Reporting. Language, Communication, Information. In Kounty, P. and Nowak, P. (Eds). 5/2010-2011. Pp. 87-99.

[10] Arcimavič̌ene, L. (2008). Moral Grounds of Sports Metaphor in Political Discourse. Cross Linguistic Analysis. In Filologia 2008(13)

[11] Silaskǐ, N. (2009). Topic Triggered Metaphors in Newspaper Headlines. In Professional Communication and Translation Studies 2 (1-2)/2009.

[12] Lakoff, G. (2003). Metaphors We Live By. Chicago and London: The University of Chicago Press.

[13] Johnson, M. (1987). The Body in the Mind. The Bodily Basis of Meaning. Imagination and Reason. Chicago, London: The University of Chicago Press.

[14] Lakoff, G. and Turner, M. (1989) More Than Cool Reason. A Field guide to Poetic Metaphor. Chicago: University Chicago Press.

[15] National AIDS Control Council (2010). "Ongoing campaigns". Website: http://www.nacc.or.ke

[16] Media/Materials Clearing House (2010). A leading international resource for health communication materials. Website:http://www.m-mc.org/mmc. (URL Consulted on the $19^{\text {th }}$ of October 2012)

[17] Alive and Kicking AIDS (2010) Alive and Kicking AIDS. Website:

http//www.aliveandkicking.org.uk/About-us/Histort.htlm. (URL Consulted on the $17^{\text {th }}$ of June 2010)

[18] LVCT Care and Treatment (2010). Ministry of Public Health and Sanitation, National AIDS and STI Control Programme in Conjunction with the stakeholders take lead in the campaign for HIV testing and Counselling during the 2010 world cup. Website: http://liverpoolvct.org. (URL consulted on the $1^{\text {st }}$ of July 2010)

[19] Fernández, E. F. (2008). Sex Related Euphemisn and Dysphemism. An Analysis in Terms of Conceptual Metaphor Theory. Journal of the Spanish Association of Anglo-American Studies, 30-2, 95-110

[20] Esau, O. (2012). "Checking HIV and AIDS: Using Chess to break the silence in the classroom". In Sahara-J: Journal of Social Aspects of HIV/AIDS. An Open Access Journal. pp.28-36

[21] Rasekh, A. and Ghafel, B. (2011). Basic Colours and Their Metaphorical Expressions in English and Persian: Lakoff's Conceptual Metaphor Theory in Focus. A paper presented in the First International Conference of Foreign Language Teaching and Applied Linguistics, May 5-7, Sarajevo. Website:http://www.eprints.ibu.edu.ba/33/1/FLTAL 2011/ProceedingsBook/p211-p224.pdf (URL consulted on $12^{\text {th }}$ December 2015) 
[22] Qiang, H. (2011). The study on the metaphor of "Red" in Chinese Culture. In American International Journal of Contemporary Research. Vol 1, No 3.

[23] He, G. (2011). A comparative study of color metaphors in English and Chinese. Theory and Practice in Language Studies. Vol 1. No 12. pp 1804-1808.

[24] Kang'ethe, I. (2004). Cognitive Efficiency: The Sheng' phenomenon in Kenya. In Pragmatics. Anthrwerp: International Pragmatics Association. Vol 14.No 1, pp. $55-67$.
[25] Swiss Federal Office of Public Health (2005). LOVE LIFE STOP AIDS. Strategy paper SFOPH AIDS campaign 2005-2008. Berne: Swiss Federal Office of Public Health

[26] Magonya, L. and Oloo, P. (2013) Biting the Conservative Bullet in Kenya! The Quagmire of Sexually Explicit and Scary Pictorial metaphors in AIDS posters. In Popular Anthropology Magazine online edition. pp. 9-20

[27] Magonya, L. (2012). A Pragmatic Analysis of Figurative Language in HIV/AIDS Discourse in Kenya. A case study of English and Kiswahili Messages. An Unpublished Ph.D. Thesis, University of Geneva, Switzerland. 